\title{
Ambient temperature and survival on a protein-deficient diet
}

\author{
By I. ANDIK, Sz. DONHOFFER, MARIA FARKAS AND P. SCHMIDT \\ Institute of Pathophysiology, University Medical School, Pécs, Hungary
}

(Received 4 October 1962-Revised I8 December 1962)

Exposure to cold has been found to prevent liver necrosis in rats fed on a proteinpoor, sucrose-rich diet deficient in vitamin $\mathrm{E}$ (Naftalin, $195 \mathrm{I}$ ), to inhibit accumulation of fat in the liver in choline deficiency (Sellers \& You, I949, I952; Treadwell, Flick \& Vahouny, I957), and to accelerate liver regeneration after removal of the left and median lobes (Moss \& Weiss, I955). In the study of Treadwell et al. (I957) growth rate and efficiency of protein utilization of rats fed on a diet with 5 or $10 \%$ protein were found to be better in the cold $\left(1^{\circ}\right)$ than at $25^{\circ}$, the reverse obtaining with diets containing 20,30 or $40 \%$ protein. When adult rats were fed on a diet containing $5 \%$ casein, and immature rats on one containing $10 \%$, the survival rate was $75-87 \%$ in the cold, whereas at $25^{\circ}$ all animals survived. Meyer \& Hargus (I959) noted that on a diet with $10 \%$ casein rats gained more weight in the cold $\left(2^{\circ}\right)$ than at $26^{\circ}$, whereas the reverse was observed when the diet contained $25 \%$ casein.

An increase in the energy expenditure, such as that which occurs in cold environments, does not necessarily mean that protein requirements simultaneously increase (Speck, I86o; Pettenkofer \& Voit, 1866). Exposure to cold $\left(5^{\circ}\right)$ increases calorie intake about twofold in the rat (Andik \& Donhoffer, 1957); it would therefore be expected that the protein content of the diet that meets energy requirements in the cold would be less than that of a diet needed to meet energy requirements at higher temperatures. Consequently, it has been postulated that a marginal content of protein could be found, insufficient to secure survival at room temperature, but permitting survival in the cold because the increased food consumption would suffice to raise protein intake above the minimum subsistence level. Our investigation was designed to put this view to the test.

\section{EXPERIMENTAL}

Male albino rats of the Institute's colony, aged 9-I I weeks at the outset, were used. Two groups of ten animals served to establish the growth rate at room temperature on diets containing 22 and $6.2 \%$ protein. The rest (thirty-five animals) received a diet containing $4.3 \%$ protein and were kept at room temperature for 3 weeks; eighteen were then transferred to a large refrigerator and seventeen remained at room temperature; both groups continued to feed on the diet containing $4.3 \%$ protein. The rats in the refrigerator remained in the cold, after the death of the animals kept at room temperature, for at least another Io days and in some instances for 21 days and were then returned to room temperature without change of diet. The experiments were spread over a year. 'The rats were divided into groups of six to eight and housed in 
individual cages, food and water being supplied ad lib.; food consumption was measured daily and body-weight recorded every and day. Room temperature was not allowed to fall below $20^{\circ}$ and, according to season, rose to 23 or $24^{\circ}$, exceptionally to

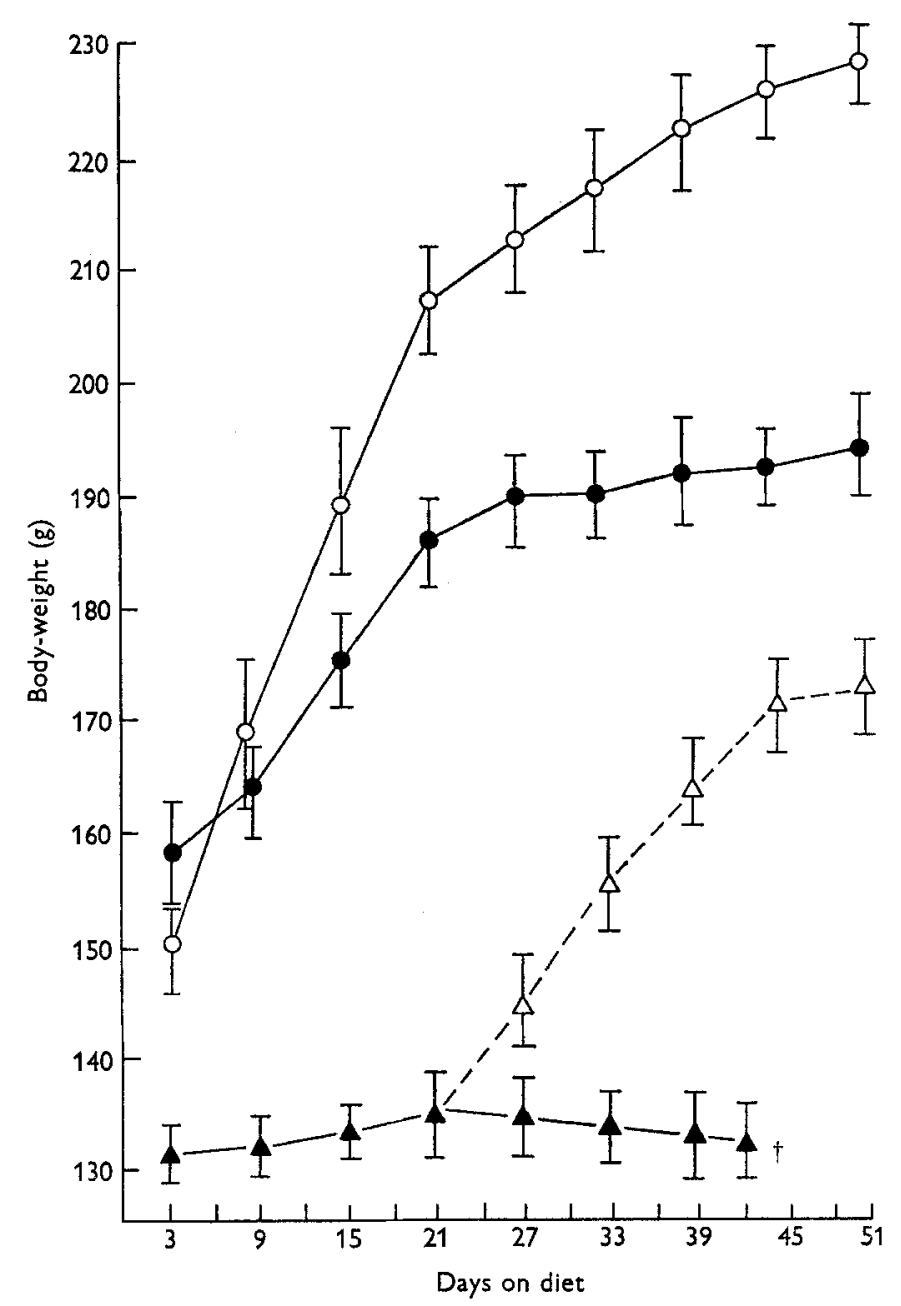

Fig. I. Growth curves of rats (mean values with standard errors) given ad lib. a diet containing $4.3 \%$ protein and kept at room temperature $\left(21^{\circ}\right.$; seventeen animals; -4$)$, or transferred after 2 I days to a cold $\left(5^{\circ}\right)$ environment (eighteen animals; $\left.\Delta-\Delta\right)$ ). $\uparrow$, shows that all of the animals in the former group died. For comparison, growth curves (mean values with their standard errors) for groups of ten animals are shown for rats at room temperature given a diet containing $22 \%(0-0)$ or $6.2 \%(-)$ protein.

$25^{\circ}$, for some hours during the day. In the refrigerator the temperature was maintained within $\pm \mathrm{r}^{\circ}$ of $5^{\circ}$. The composition of the $22 \%$ protein diet was $(\mathrm{g})$ : ground maize $255^{\circ}$, casein 400 , dried brewer's yeast I $_{5}^{\circ}, \mathrm{CaCO}_{3}$ I $_{5}, \mathrm{NaCl}_{1}$, iron citrate 3 and $\mathrm{KI} 0.12$. For the 6.2 and $4.3 \%$ protein diets an appropriate amount of casein was replaced by maize starch. The protein content calculated from tables agreed reasonably well with occasional measurements of the nitrogen content by Kjeldahl's method. 


\section{RESULTS}

Fig. I demonstrates that the rats survived at room temperature on the diet containing $6.2 \%$ protein, although the growth rate was markedly reduced in comparison with that of the animals having the $22 \%$ protein diet. None of the rats on the $6.2 \%$ protein diet died in the course of the experiment. On the $4.3 \%$ protein diet at room temperature the rats not only failed to gain weight, but all of them died towards or shortly after the end of the 6th week. Rats fed on the same diet but transferred after 3 weeks into the cold not only survived the experiment but also gained weight. All animals removed from the cold into room temperature immediately ceased to gain weight and died within a few weeks.

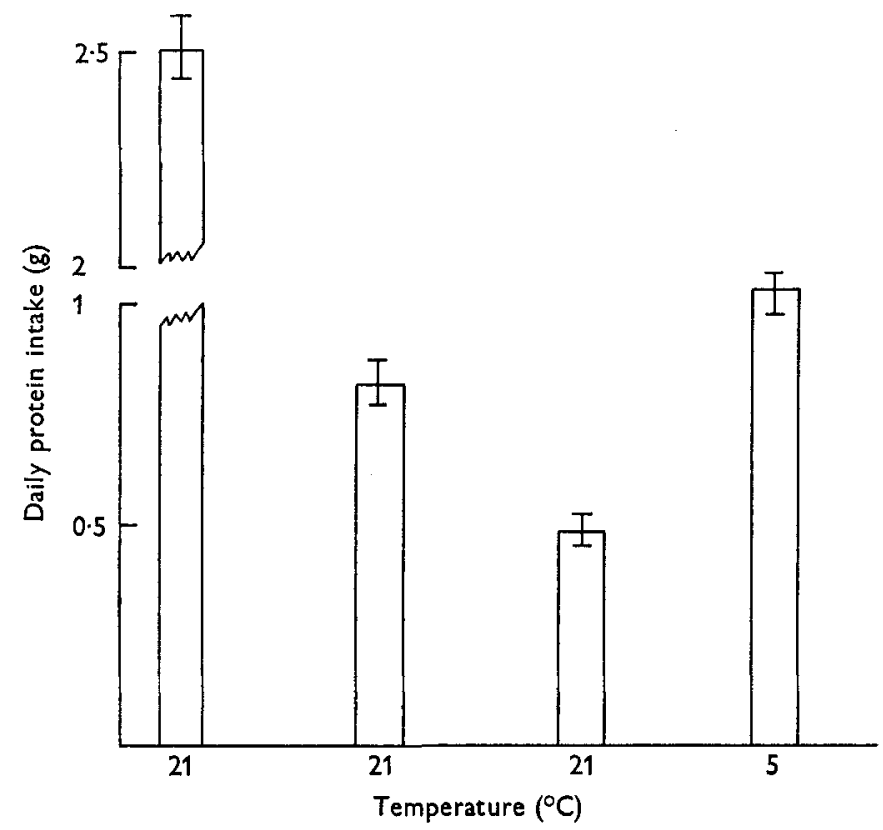

Fig. 2. Daily protein intake (mean values with their standard errors, reading from left to right) of rats at room temperature given diets containing $22 \%$ (ten animals), $6.2 \%$ (ten animals) or $4.3 \%$ protein (seventeen animals), and of rats exposed to cold and fed on a $4.3 \%$ protein diet (eighteen animals).

Fig. 2 explains these observations. In the cold, protein intake, along with the intake of calories, exceeded that at room temperature by a factor of about 2 , and rose significantly above the intake at room temperature from the $6 \cdot 2 \%$ protein diet.

\section{DISCUSSION}

The results appear clear-cut. Rats survived and gained weight in the cold on a lowprotein diet that invariably led to death at room temperature. This observation is in keeping with the established fact that food intake by the rat is primarily governed by its calorie requirement (Yoshida, Harper \& Elvehjem, 1957). At room temperature, 
therefore, the calorie intake was almost identical in the groups fed on diets containing 4.3 and $6 \cdot 2 \%$ protein $(27 \cdot 4 \pm 3.8$ and $27 \cdot 8 \pm 3.6 \mathrm{kcal} / \mathrm{I}$ oo $\mathrm{g}$ body-weight daily, respectively); the rats fed on the diet containing $22 \%$ protein and gaining bodyweight rapidly consumed somewhat more $\left(30 \pm 4^{\circ} \circ \mathrm{kcal} / \mathrm{r} 00 \mathrm{~g}\right.$ body-weight daily), the difference not being statistically significant.

This result is in complete agreement with the observation of Yoshida et al. (1957) that calorie intake per unit of body-weight is constant even if growth is limited by an inadequate protein intake, whereas total calorie intake is, within a certain range, a function of the protein level. The protein : calorie ratio is a useful indicator in nutrition (Schreiber \& Elvehjem, 1955; Donaldson, Combs \& Romoser, 1956; Yoshida et al. I957) and has been used to express the effective protein content of the diet (Miller \& Payne, I $96 \mathrm{I} a, b)$. When energy expenditure and consequently calorie intake varies, the protein:calorie ratio alone fails to indicate correctly the nutritional value of lowprotein diets, if used independently of total calorie intake. In our experiments severe protein deficiency developed and death ensued on the diet containing $4.3 \%$ protein at room temperature, whereas rats exposed to cold not only survived, but even gained weight on the same diet by consuming, in proportion to the increased rate of metabolism, approximately twice the amount of calories, and hence of protein.

An increase in food intake accounts most probably also for the favourable effect of exposure to cold observed by Naftalin (195I), Sellers \& You (1949, I952) and Treadwell et al. (1957) in lipotropic-factor deficiency, and for the acceleration of liver regeneration in the experiments of Moss \& Weiss (I955). No explanation can be offered for the discrepancy between our results and some of the observations of Treadwell et al. (1957), according to which rats on a $5 \%$ casein diet (a) failed to increase their food intake in the cold and, nevertheless, showed a better growth rate than at $25^{\circ}$, and $(b)$ all rats survived at $25^{\circ}$, whereas in the cold some on the same diet died. The cited observations of Meyer \& Hargus (1959) are in agreement with our results.

Cold and a protein-poor diet are both considered to be unfavourable factors for the animal or, in other words, subject the animal to stress. Yet exposure to the one unfavourable factor, cold, permits survival on the unfavourable diet that in circumstances generally considered more favourable leads inevitably to death. Such interrelations of environmental factors sometimes fail to receive due appreciation.

\section{SUMMARY}

I. Male rats were fed ad lib. at room temperature on diets containing $22,6.2$ or $4.3 \%$ protein. After 3 weeks on the diet containing $4.3 \%$ protein, eighteen of thirtyfive rats were transferred to an environmental temperature of $5^{\circ}$ for $7-9$ weeks and then returned to room temperature. Food consumption was measured daily and bodyweight recorded every 2 nd day.

2. Rats kept at room temperature and fed on the diet containing $4.3 \%$ protein immediately ceased to gain weight and all died during, or shortly after the end of, the 6th week on the diet.

3. Animals transferred after the $3^{\text {rd }}$ week to the cold $\left(5^{\circ}\right)$ immediately began to 
gain weight on the same diet and all of them survived while in the cold. Re-transfer to room temperature was followed by immediate cessation of body-weight gain, and in a few weeks death ensued.

4. The fact that food intake, and with it protein intake, approximately doubled in the cold, explains the observation. Low-protein diets are not characterized adequately by their protein: calorie ratio without the consideration of total calorie intake.

\section{REFERENCES}

Andik, I. \& Donhoffer, Sz. (1957). Pflüg. Arch. ges. Physiol. 264, 585.

Donaldson, W. E., Combs, G. F. \& Romoser, G. L. (1956). Poult. Sci. 35, 1 100.

Meyer, J. H. \& Hargus, W. A. (1959). Amer. F. Physiol. 197, 1350.

Miller, D. S. \& Payne, P. R. (I96ra). Brit. F. Nutr. I5, Iт.

Miller, D. S. \& Payne, P. R. (I96I b). F. Nutr. 74, 4I3.

Moss, W. G. \& Weiss, A. K. (I955). Fed. Proc. 14, 104.

Naftalin, J. M. (1951). F. Path. Bact. 63, 649.

Pettenkofer, M. \& Voit, E. (1866). Z. Biol. 2, 537.

Schreiber, M. \& Elvehjem, C. A. (1955). F. Nutr. 57, 133.

Sellers, E. A. \& You, R. W. (1949). Science, 110, 713.

Sellers, E. A. \& You, R. W. (1952). Biochem. F. 51, 573.

Speck, C. (1860). Arch. wiss. Heilk. 4, 521.

Treadwell, C. R., Flick, D. F. \& Vahouny, G. V. (I957). F. Nutr. 63, 61 I.

Yoshida, A., Harper, A. E. \& Elvehjem, C. A. (1957). F. Nutr. 63, 555. 